\section{BMJ Paediatrics Open}

\title{
The health impact on children affected by parental imprisonment
}

\author{
Sarah Beresford (D , ${ }^{1}$ Nancy Loucks, ${ }^{2,3}$ Ben Raikes ${ }^{4}$
}

To cite: Beresford S, Loucks N, Raikes B. The health impact on children affected by parental imprisonment. BMJ Paediatrics Open 2020;4:e000275. doi:10.1136/ bmjpo-2018-000275

Received 6 December 2019 Revised 17 January 2020 Accepted 23 January 2020
Check for updates

(C) Author(s) (or their employer(s)) 2020. Re-use permitted under CC BY-NC. No commercial re-use. See rights and permissions. Published by BMJ.

${ }^{1}$ Prison Reform Trust, London, UK

${ }^{2}$ Criminology, University of Strathclyde, Glasgow, UK

${ }^{3}$ Families Outside, Edinburgh, UK ${ }^{4}$ Behavioural and Social Sciences, University of Huddersfield, Huddersfield, UK

Correspondence to Sarah Beresford; s.g. roberts44@gmail.com

\section{INTRODUCTION}

Scotland, England and Wales have the highest imprisonment rates in Western Europe. ${ }^{1}$ A number of studies ${ }^{2}$ have highlighted the devastating impact of parental imprisonment on children. As well as a significant sense of loss, many children experience stigma, social isolation, shame and fear. ${ }^{3}$ This underlines the need to use non-custodial measures wherever possible to reduce the disruption and trauma of a parent's imprisonment. ${ }^{4}$ Parental imprisonment can have a negative impact on children's short-term emotional well-being, as well as their long-term health and social prospects. ${ }^{5}$ Women, who are more likely to be primary carers, tend to receive short sentences for non-violent crimes without consideration of the impact on their children. ${ }^{6}$ Separation from a mother is particularly traumatic, and children affected often face greater disruption as it is more likely to involve other changes (eg, carer, home and school).$^{7}$ Children with imprisoned mothers often reside with grandparents, who may also need practical and financial support. ${ }^{8}$

Despite the adversities they face, children affected by imprisonment are rarely recognised as a distinct group within the systems and structures that should protect them, and no government agency is responsible for their well-being. ${ }^{9}$ While no systematic recording and monitoring system is in place, a 2019 report estimates that around 312000 children are affected annually by parental imprisonment in England and Wales. ${ }^{10}$

\section{PARENTAL IMPRISONMENT IS AN ACE}

The imprisonment of a household member is one of the ten adverse childhood experiences (ACEs) known to have a significant impact on long-term health and well-being. ${ }^{11}$ Further, the imprisonment of a household member is associated with a fivefold increase in exposure to other ACEs. ${ }^{12}$ The more ACEs a child suffers, the more likely this is to impact negatively on outcomes in terms of health, school attainment and later life experiences. Recent research has highlighted that those with a higher exposure to ACEs are more likely to go on to develop health-harming and antisocial behaviours, such as binge drinking, smoking and drug use. ${ }^{13}$ Poor health and social behaviour can lead to a more rapid development of diseases such as diabetes, cancer, cardiovascular disease and mental illness. ${ }^{14}$

\section{THE IMPACT ON HEALTH}

A major pan-European study (COPING) investigated the mental health needs of children affected by parental imprisonment and children's resilience and coping strategies. ${ }^{15}$ With an explicitly child-centred approach, the COPING study concluded that these children are at a significantly greater risk of suffering mental health difficulties than children who do not have parents in prison. Children with a parent in prison may experience low self-esteem, depression, disturbed sleeping patterns and symptoms of posttraumatic stress. ${ }^{16}$ In a North American study, separation from a parent through imprisonment was found to be more detrimental to a child's well-being than divorce or the death of a parent. ${ }^{17}$

A significant number of UK children in the COPING study needed to access counselling or other kinds of support outside the family. However, while a range of services and interventions exist, these are not often targeted towards the needs of children of prisoners; services are patchy, uncoordinated and accessible by only a relatively small number of children. Many children of prisoners do not have enough support and often do not speak about what they have experienced, which may explain why they are more likely to experience mental health problems than other children. $^{18}$ 
An American study showed that children of incarcerated parents are a vulnerable population who experience disadvantages across an array of health outcomes, including learning disabilities, attention deficit disorder and attention deficit hyperactivity disorder, developmental delays, speech or language problems, as well as a higher rate of physical health conditions such as asthma and obesity. ${ }^{19}$ A recent Dutch study suggests a link between parental imprisonment and premature death. ${ }^{20}$

\section{WHAT CAN HEALTH PROFESSIONALS D0?}

Families affected by imprisonment are often reluctant to access support from outside agencies. ${ }^{21}$ This may be due to shame and stigma, a lack of knowledge of what support is available, or a mistrust of statutory services. Health professionals who have an established relationship with families can be a gateway to further support and can ensure that staff are aware of, and trained in how to recognise and deal with, issues around imprisonment. ${ }^{22}$ Health professionals are well placed to build positive relationships actively with families affected by imprisonment and help carers to access additional forms of support. They can ensure families are aware of the full range of services available to them, including those that support families affected by substance misuse, domestic abuse, or physical or mental health problems, and can encourage family members to engage with other agencies in the community.

\section{SEEING THE POTENTIAL IN EVERY CHILD}

Some studies suggest that children of prisoners are more likely to end up in the criminal justice system as adults ${ }^{23}$ or be involved in antisocial behaviour. ${ }^{24}$ What is crucial to understand, however, is that criminality is not an infection that can be passed on; rather it is the grief experienced by children, compounded by trauma, stigma, and practical implications such as loss of income or housing, which can lead to disengagement from school and a mistrust of authority. This in turn increases the potential to be involved in at-risk behaviour. In other words, it is not the imprisonment of the parent in and of itself, but the response to the imprisonment (social isolation and a sense of shame in addition to trauma) that increases the risk factor.

Primary health teams, with positive relationships with children and their families, can help children by seeing the potential they have, rather than the problems they face. As a YouTube video ${ }^{25}$ demonstrates, if children and young people are given a vision of hope, and feel that they have potential to change, it can make all the difference. Having a parent in prison is one of life's most challenging experiences, but it does not have to define a child's life. Primary healthcare professionals are key to helping each child realise their potential.
Contributors All three authors of this editorial piece have extensive experience on research related to the impacty of parental imprisonment on children and contributed to its content. The article was planned and submitted by SB, with significant contributions from NL and BR. NL performed the final editing of the article.

Funding The authors have not declared a specific grant for this research from any funding agency in the public, commercial or not-for-profit sectors.

Competing interests None declared.

Patient consent for publication Not required.

Provenance and peer review Commissioned; externally peer reviewed.

Open access This is an open access article distributed in accordance with the Creative Commons Attribution Non Commercial (CC BY-NC 4.0) license, which permits others to distribute, remix, adapt, build upon this work non-commercially, and license their derivative works on different terms, provided the original work is properly cited, appropriate credit is given, any changes made indicated, and the use is non-commercial. See: http://creativecommons.org/licenses/by-nc/4.0/.

ORCID iD

Sarah Beresford http://orcid.org/0000-0001-8634-6827

\section{REFERENCES}

1 World prison brief, 2020. Available: https://www.prisonstudies.org/ highest-to-lowest/prison_population_rate?field_region_taxonomy tid=14 [Accessed 9 Jan 2020].

2 Condry R, Scharff Smith P. Prisons, punishment, and the family: towards a new sociology of punishment? Oxford University Press, 2018.

3 Available: childrenofprisoners.eu/the-issues/

4 Council of Europe. Recommendation CM/Rec (2018) 5 of the Committee of Ministers to member States concerning children with imprisoned parents [online], 2018. Available: https://search.coe. int/cm/Pages/result_details.aspx?OObjectld=09000016807b3175 [Accessed 9 Jan 2020].

5 McGillivray C. Rendering them Visible: a review of progress towards increasing awareness and support of prisoners' families. Edinburgh: Families Outside, 2016. https://www.familiesoutside.org.uk/content/ uploads/2017/12/Rendering-Them-Visible-FINAL.pdf

6 Baldwin L, Epstein R. Short but not sweet: a study of the impact of short custodial sentences on mothers and their children. Leicester: De Montfort University, 2017.

7 Minson S. Who cares? analysing the place of children in maternal sentencing decisions in England and Wales. DPhil thesis, University of Oxford. Also Beresford, S. (2018) What about me? The impact on children when mothers are involved in the criminal justice system. London: Prison Reform Trust, 2017.

8 Raikes B. Unsung heroines: celebrating the care provided by grandmothers for children with parents in prison. Probation Journal 2016;63:320-30.

9 Williams K, Papadopoulou V, Booth N. Prisoners' childhood and family backgrounds: Results from the Surveying Prisoner Crime Reduction (SPCR) Longitudinal Cohort Study of Prisoners. London: Ministry of Justice, 2012.

10 Op. CIT. See endnote 1 above.

11 Felitti VJ, Anda RF, Nordenberg D, et al. Relationship of childhood abuse and household dysfunction to many of the leading causes of death in adults. Am J Prev Med 1998;14:245-58.

12 Turney K. Adverse childhood experiences among children of incarcerated parents. Child Youth Serv Rev 2018;89:218-25.

13 Health Scotland. Tackling the attainment gap by preventing and responding to adverse childhood experiences (ACEs). 2017.

14 Turney K. Op CIT. Endnote 8.

15 Jones A, Gallagher B, Manby M, et al. COPING: Children of Prisoners, Interventions \& Mitigations to Strengthen Mental Health 2013.

16 Myers BJ, Smarsh TM, Amlund-Hagen K, et al. 'Children of Incarcerated Mothers'. J Child Fam Stud 1999;8:11-25.

17 Dumont DM, Allen SA, Rich JD. Sesame Street Goes to Jail: Physicians Should Follow. Ann Intern Med 2014;161:522-3.

18 Jones. Op CIT. Endnote 10.

19 Turney K. Stress proliferation across generations? Examining the relationship between parental incarceration and childhood health. $J$ Health Soc Behav 2014;55:302-19.

20 van de Weijer SGA, Smallbone HS, Bouwman V. Parental imprisonment and premature mortality in adulthood. J Dev Life Course Criminol 2018;4:148-61. 
21 Pugh G, Lanskey C. "'Dads Inside and Out': study of risk and protective factors in the resettlement of imprisoned fathers with their families". Conference paper for What's new in Research and Evaluation? Informing our work with prisoners and offenders and their families. 2011. Institute of Criminology, University of Cambridge, 2011.

22 Outside F. (n.d.) Supporting Prisoners' Families: What can Health Professionals do? Edinburgh: Families Outside. Available: https:// www.familiesoutside.org.uk/content/uploads/2019/07/FamiliesOutside-Health-web.pdf [Accessed 14 Nov 2019]
23 Butterfield F. Parents in prison: a special report: as inmate population grows, so does a focus on children. New York Times 1999.

24 Murray J, Farrington DP. The Effects of Parental Imprisonment on Children,". In: Tonry M, ed. Crime and justice: a review of research 37. Chicago: University of Chicago Press, 2008: 133-206.

25 Available: https://www.youtube.com/watch?v=kKZPOQKnNYg [Accessed 14 Nov 2019]. 